\title{
How Can We Estimate Buffer Zones of Protected Areas? A Proposal Using Biological Data
}

\author{
Brenda Alexandre ${ }^{1}$, Renato Crouzeilles ${ }^{1,2} \&$ Carlos Eduardo Viveiros Grelle ${ }^{1, \star}$
}

${ }^{1}$ Laboratório de Vertebrados, Departamento de Ecologia, Universidade Federal do Rio de Janeiro - UFRJ

${ }^{2}$ Programa de Pós-graduação em Ecologia, Instituto de Biologia, Universidade Federal do Rio de Janeiro - UFRJ

\begin{abstract}
A strategy to avoid the loss of habitats and preserve large areas is the establishment of protected areas. Brazil's Conservation Units National System (SNUC) determines that protected areas should be surrounded by buffer zones where human activity is restrict, but the established size of the buffer seems arbitrary. The restrictions provided by SNUC could be based on limits that allow the persistence of species' ecological function. Here we use the "landscape species" concept as a tool for buffer zone design, using the marsupial Micoureus paraguayanus as a model organism. We used its minimum area requirement for population viability (5,000 ha) to define the size of buffer zones around protected areas with smaller size that the minimum required area. The amount of habitat within protected areas was negatively correlated with the buffer size. Therefore, the largest the protected area, the smaller should be its buffer zone, provided that it does not have an impermeable barrier. Buffer zones are generally in private properties and, therefore, governmental incentives are essential to stimulate land uses compatible with biological flux through a permeable matrix. The method proposed here provides a simple analysis that can be used to establish the limits of buffer zones.
\end{abstract}

Key words: Buffer Zones, Atlantic Forest, Landscape Species, Micoureus paraguayanus, Reserve Design.

\section{Introduction}

Protected areas are elements of complex landscapes that should be managed, allowing the persistence of viable populations and the use for some economic activities (Crooks \& Sanjayan 2006). For protected areas to maintain viable populations at the long-term, a minimum amount of habitat area is needed in a single area, or a network with other habitat patches where potential connectivity is possible. Connectivity can be defined as the degree to which the landscape facilitates or impedes movement among resource patches. It can be divided into "structural connectivity", which refers to the spatial arrangement of the elements of the landscape, and "functional connectivity", which refers to the behavior response of organisms to landscape structures (Crooks \& Sanjayan 2006).

On the other hand, to reconcile conservation and land-use one of the alternatives is to establish buffer zones around protected areas, within which human activities are subjected to specific rules and restrictions (Gonçalves et al. 2009). In Brazil, the protected areas system was established in 2000 by law No 9.985 of the Conservation Units National System

\footnotetext{
${ }^{\star}$ Send correspondence to: Carlos Eduardo Viveiros Grelle Laboratório de Vertebrados, Departamento de Ecologia, Universidade Federal do Rio de Janeiro - UFRJ, CP 68020, CEP 21941-590, Rio de Janeiro, RJ, Brasil E-mail: grellece@biologia.ufrj.br
}

(SNUC, in the Portuguese acronym), where buffer zones are transition areas that should minimize negative impacts on protected areas. The size of buffer zones is not specified in SNUC, however. In 1990, the National Environment Council Resolution (CONAMA, Portuguese acronym) $\mathrm{N}^{\circ} 13$ had already defined a $10 \mathrm{~km}$ buffer zone around protected areas, where any activity that may affect the biota should be licensed (Gonçalves et al. 2009). The size proposed by CONAMA, however, is arbitrary and may be inadequate to maintain minimum viable population of some species. Studies performed in wetlands already showed the inefficiency of arbitrary buffer zones to population viability of frogs and salamanders (Harper et al. 2008).

Conservation strategies need to be based on data, preferably data that allow for the interaction between biological and socio-economic perspectives. The "landscape species" approach has been used to characterize impacts on the structure and functioning of natural systems (Sanderson et al. 2002). It arises as a tool to be used in strategies for conservation and public policies. In this approach, the species are chosen based on the heterogeneity of its habitats, land uses and vulnerability to anthropogenic pressure, ecological functionally and socio-economic significance (Sanderson et al. 2002). 
Putting together the landscape species approach and the minimum area needed for species' long-term persistence, it is possible to draw a proposal to delimit buffer zones. Thus, it is expected that the larger the protected area, the smaller should be its buffer zone to achieve a threshold of habitat amount to long-term persistence of populations. However, in highly fragmented landscapes, besides of the amount of forest cover within the protected area, the buffer zone may be enlarged or reduced depending on the amount and arrangement of the natural remnants surrounding protected areas.

In this study, the marsupial Micoureus paraguayanus was used as a landscape species to delimit buffer zones. This small species is endemic to the Brazilian Atlantic forest and needs a minimum area of 5,000 ha to maintain a viable population over the long term (Brito \& Grelle 2004). We used the minimum forested area required by the species to define the size of buffer zone around protected areas $>5,000$ ha. We also evaluated whether the increase of forest cover inside protected areas translates into a decrease in the size of buffer zones.

\section{Material and Methods}

\section{Region of study}

Rio de Janeiro state is located in southeastern Brazil. Its original vegetation is Atlantic forest, which has been radically transformed since the 1500's (Fundação SOS Mata Atlântica \& INPE 2010). Rio de Janeiro has more than 16 million people (http://www.ibge.gov.br/estadosat/ perfil.php?sigla=rj accessed on 12 July 2010), 43.6 million hectares of total area, of which about 800 thousand hectares of forest (or $18 \%$ of the state' area, Fundação SOS Mata Atlântica \& INPE 2010). Approximately 14\% of the forest remnants are under protected areas (Jenkins et al. 2010), which can be divided into two classes: Strictly Protected Areas and Sustainable-Use Areas. The former corresponds to categories I-IV of the IUCN, which is established to maintain biodiversity and increase the protection, whereas the second corresponds to categories V-VI of the IUCN, which has the main focus of conciliate conservation and economical activities. Strictly protected areas have $77 \%$ of forest cover (Fidalgo et al. 2009) and protect about 6\% of the remaining forest (Jenkins et al. 2010), but sustainable-use areas have only $43 \%$ of forest cover (Fidalgo et al. 2009). According the SNUC, protected areas should be surrounded by buffer zones, but this rule has two exceptions in sustainable-use categories: Environmental Protection Area (APA) and Private Natural Heritage Reserve (RPPN).

The forest cover map used is from the cartographic base of Fundação SOS Mata Atlântica \& INPE (2010), resulting from TM/Landsat bands 5 or 7, obtained at a scale of 1:50,000 in vector format, mapping forest remnants with at least 10 ha. The land-use map used is from Brazilian Environment Ministerial (MMA in portuguese acronym - http://mapas. mma.gov.br/mapas/aplic/probio accessed on November $10^{\text {th }}$, 2008) and the shapes of protected areas (27 strictly areas and 21 sustainable-use) were downloaded from Brazilian Institute of Environment and Renewable Resource (IBAMA in portuguese acronym - www.ibama.gov.br/patrimonio/ accessed on March, $\left.5^{\text {th }}, 2008\right)$. All geographical information data used were in Albers projection.

\section{Micoureus paraguayanus as a "Landscape species"}

Micoureus paraguayanus (previously Micoureus travasossi) is a small didelphid whose adult can weigh up to $130 \mathrm{~g}$, males being slightly larger than females (Rossi et al. 2006). It can be found in dense forest and also in secondary vegetation, it is nocturnal and mostly arboreal, although it can descends to the ground (Grelle 2003). The species is widely distributed in the state of Rio de Janeiro, occurring in all vegetation types but campos de altitude (highland fields occurring above 2000 a.s.l) (C.E.V. Grelle unpublished data). The species may cross up to $100 \mathrm{~m}$ in matrices composed of grass (Forero-Medina \& Vieira 2009), and up to $300 \mathrm{~m}$ in matrices composed of grasses, shrubs and pioneer trees (Pires et al. 2002). According to Brito \& Grelle (2004), M. paraguayanus needs a minimum of 5,000 ha forested area to support a viable population of 2,000 individuals that will retain demographic and genetic integrity for 100 years. We used $M$. paraguayanus as landscape species because it has not only the appropriate behavioral ecology, but also sufficient and appropriate data. The species occurs in heterogeneous habitat, being found in different successional stages of vegetation (Forero-Medina \& Vieira 2009; Grelle 2003, Pires et al. 2002). It has an important ecological function as seeds disperser (Cáceres et al. 2002), is vulnerable to anthropogenic threats (Umetsu et al. 2008), but even so it may cross different human modified landscapes such as coffee plantation, and has socio-economic significance (Passamani \& Ribeiro 2009).

\section{Delimiting buffer zones}

First, we overlie the forest cover and protected areas maps, determining the actual amount of forested habitat for each protected area. Then, we evaluated which protected areas needed buffer zones according SNUC, and which were $>5,000$ ha (i.e., the estimated minimum area needed for $M$. paraguayanus). The protected areas that were not large enough, but were structurally connected to other protected areas or forest remnants, were not included in the analysis, even if together with its connecting elements it exceeded 5,000 ha.

For the other protected areas, buffers were created according to protected areas boundaries, drawing concentric areas. Buffer size is then expressed as the radius of these circles and expressed in $\mathrm{km}$. The surrounding forest remnants were incorporated until the total achieved the 5,000 ha landmark. 
In each buffer zone, the land use/cover was classified into five categories, according to M. paraguayanus preferences: forest remnants (habitat patches), simple matrix (grass; low permeability), complex matrix (grasses, shrubs and pioneer trees; high permeability), large water bodies and urban areas (impermeable). All analyses were performed using ArcView 9.3 (ESRI 2008).

Finally, we tested how the increase of forest cover in protected areas translated into a decrease in buffer zone size, because of the variation in forest cover within protected areas. Spatial autocorrelation in these variables (forest cover and buffer zone size) were tested using Moran's $I$ correlograms with five distance classes. To take into account the effects of autocorrelation when correlating buffer size and forest cover, we calculated geographically effective degrees of freedom $\left(v^{*}\right)$ based on the correlograms (Legendre P. \& Legendre L. 1998). All spatial analyses were obtained in SAM (Spatial Analysis in Macroecology), version 4.0, freely available at www.ecoevol.ufg.br/sam (Rangel et al. 2010).

\section{Results}

Altogether, 31 out of the 48 protected areas in Rio de Janeiro state required buffer zones as proposed in the SNUC. Of these, 16 were smaller than the minimum requirement for $M$. paraguayanus. For these, the average buffer zones size was $9.3 \mathrm{~km}$ (Table 1, Figure 1). The protected area with the largest forest cover was "Ilha Grande State Park" (4,302 ha), and that needed the smallest buffer zone $(0.45 \mathrm{~km})$, whereas the "Guaxandiba" Ecological Station (1,241 ha) required the largest buffer zone $(27.15 \mathrm{~km})$ (Table 1$)$.

Forest Cover and Buffer Zone Size showed a weak and non-significant autocorrelation pattern (Moran's $I=0.161$,
$P=0.358$ and Moran's $I=0.186, P=0.301$, respectively, for the first distance class, around $30 \mathrm{~km}$ ). Despite the Guaxindiba protected area tends to be an outlier in the relationship, there is a significant correlation between Forest Cover and Buffer Zone Size, even taking into account the small effects of spatial autocorrelation $\left(r=-0.52, v^{*}=13\right.$, $P=0.042$; Figure 2). A log-transformation of the buffer size increases the linearity of the relationship, but the relationship in the original data was shown to reveal the larger variance and uncertainty in the buffer size surrounding small protected areas.

Five protected areas required buffer zones larger than $10 \mathrm{~km}$ and 10 protected areas had urbanization and/or water bodies in its interior, which are impermeable to the movement of $M$. paraguayanus.

\section{Discussion}

Protected areas must be effective to conserve nature, and need to be planned in an association of stakeholders and scientists (Albernaz \& Souza 2007; Grelle et al. 2010). In reality, most legal actions and guidelines have been defined in an arbitrary way, without considering ecological processes (e.g. Hunter et al. 2009). Ecological processes can be quantified in many ways (e.g. minimum forest cover needed for species persistence in forested biomes), which may allow objective definitions of conservation goals (Ficetola \& Denoël 2009).

In Brazil, environmental guidelines are determined through legal instruments, as SNUC and CONAMA. However, in some cases, the specifications are insufficient and poorly defined. SNUC determines that the buffer zones should be established by each protected area's management plan,

Table 1. Forest cover, buffer zone size, and landscape elements within buffer zones for the 16 protected areas in Rio de Janeiro State that were smaller than the minimum requirement for $M$. paraguayanus. Landscape elements: (a) forest remnants, (b) complex matrix, (c) simple matrix, (d) water bodies, (e) urban area. S.P - State Park, E.R - Ecological Reserve, B.R. - Biological Reserve, S.R. - State Reserve, N.F. - Natural Forest, N.P - National Park, E.S. - Ecological Station.

\begin{tabular}{|c|c|c|c|}
\hline Protected area and category & Forest cover (ha) & Buffer size $(\mathbf{k m})$ & Landscape elements \\
\hline Chacrinha S.P & 12.16 & 13.2 & a.c.d.e \\
\hline Jacarepia E.R. & 74.88 & 16.5 & a.b.c.d \\
\hline Guaratiba B.R & 87.44 & 5.45 & a.b.c.e \\
\hline Alcobaca S.R. & 98.99 & 6.5 & a.e \\
\hline Grajaú S.P. & 100.65 & 12.75 & a.b.c.d.e \\
\hline Massambaba E.R. & 287.94 & 21.4 & a.b.c.d.e \\
\hline Mário Xavier N.F. & 499.00 & 9.2 & a.c.e \\
\hline Serra da Concordia S.P. & 796.65 & 6.4 & a.c \\
\hline Serra da Tiririca S.P. & $1,072.69$ & 8.0 & a.b.c.e \\
\hline Guaxandiba E.S. & $1,241.30$ & 27.15 & a.b.c.d \\
\hline Araras B.R. & $1,412.33$ & 3.1 & a \\
\hline Marinho do Aventureiro S.P. & $1,785.85$ & 3.8 & a \\
\hline União B.R. & $2,053.53$ & 9.6 & a.b.c.d.e \\
\hline Tijuca N.P. & $2,615.37$ & 4.6 & a.c \\
\hline Praia do Sul E.R. & $3,438.82$ & 0.9 & $\mathrm{a}$ \\
\hline Ilha Grande S.P. & $4,302.10$ & 0.45 & $\mathrm{a}$ \\
\hline
\end{tabular}




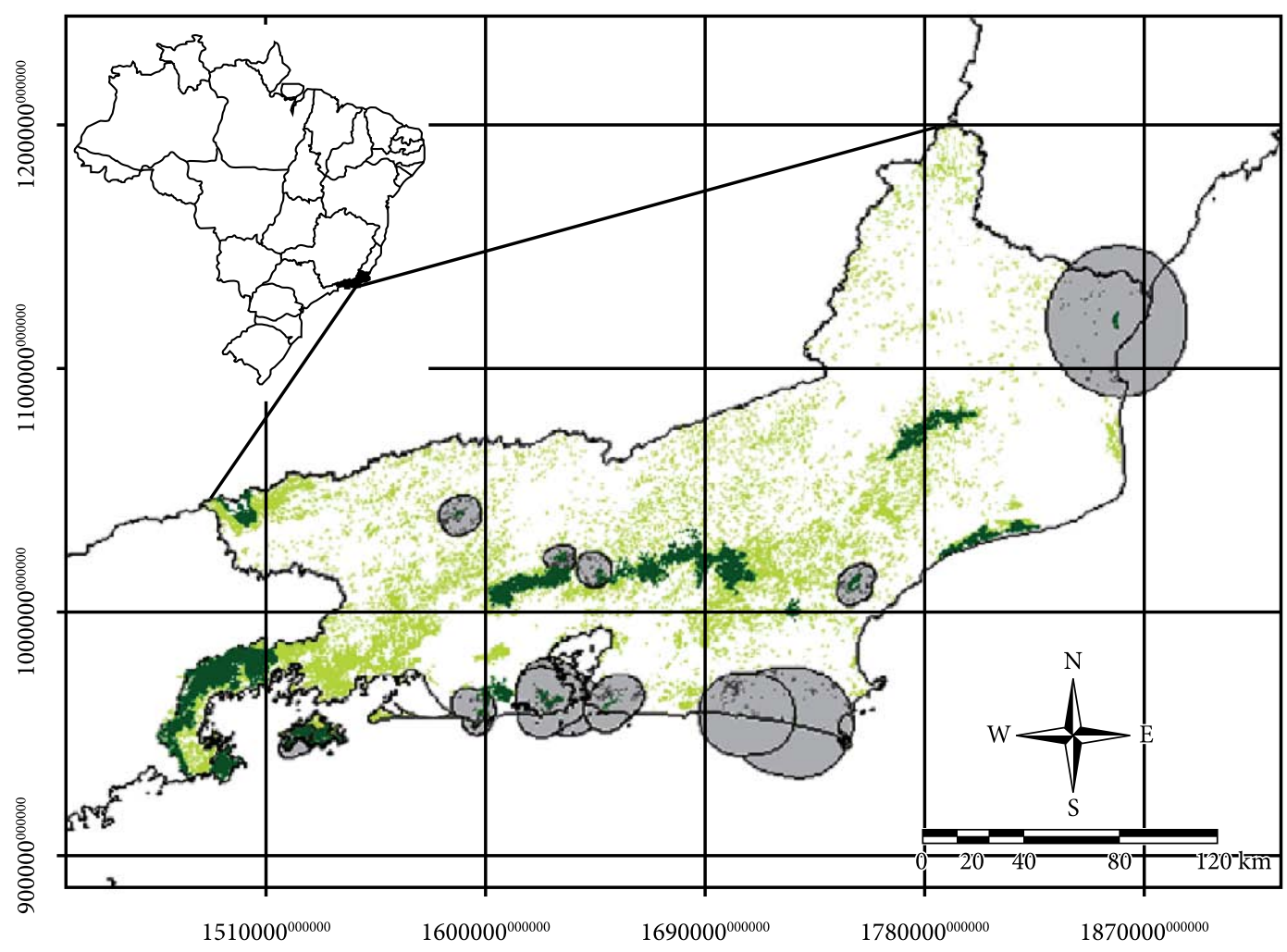

Protected area vegeted $\square$ Rio de Janeiro State $\square$ Forest remnats $\square$ Buffers of protected areas

Figure 1. Buffer Zones with forest remnants surrounding protected areas in Rio de Janeiro State

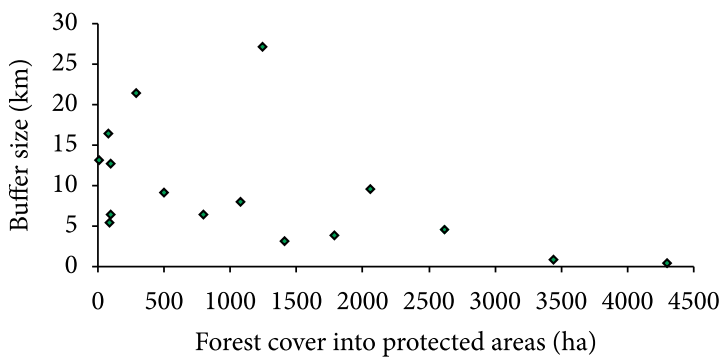

Figure 2. Relationship between forest cover and buffer zone size in protected areas in Rio de Janeiro State that were smaller than the minimum requirement for $M$. paraguayanus.

without any specification regarding buffer zone's size (Vitalli et al. 2009), and CONAMA arbitrarily require protected areas to have a $10 \mathrm{~km}$ buffer zones surrounding it. The science of determining buffer zones and surrounding areas is very immature, and need more attention. The functional essence of buffer zones is to act as transition areas that should minimize disturbance in protected areas. The size is very important in that sense, as it may be inadequate to deal with the ecological needs of species (e.g. sustain minimum viable populations - Harper et al. 2008).
We found that, for a small landscape species (M. paraguayanus), the average size of buffer zones needed to maintain population viability was lower than $10 \mathrm{~km}$ proposed by CONAMA. However, five protected areas would need a larger buffer zone than the proposal. Moreover, not all protected areas needed a buffer zone, because these protected areas were already larger than the minimum required by the species. It is important to note, however, that $M$. paraguayanus is a small species. The result would be different for other species, such as the primate Brachyteles hypoxantus, which requires a minimum forested area of 11.600 ha (Brito \& Grelle 2006) and had been proposed as landscape species (Cunha \& Grelle 2008). However, currently this primate has a restrict distribution in the state of Rio de Janeiro (Cunha et al. 2009). Therefore, a single buffer size may be insufficient to maintain ecological processes structured in the landscape.

Conservation planning and actions should be based on ecological needs of species, and here we used the landscape species concept as tool for conservation action. Besides landscape species, there are other kinds of approaches related to target species that can be used in conservation planning, such as focal species, umbrella species and flagship species (Caro et al. 2004). The landscape species approach 
differs from these in that it depends on the composition and configuration of the landscapes, focusing not only in the conservation of sympatric species, but also in the conservation of the landscape structure, including the ecological functions that depend on landscape heterogeneity (Sanderson et al. 2002).

The restrictions provided by law to buffer zones could be based on limits that maintain the ecological function of species (e.g. connectivity). Therefore, the size of buffers zones should be enlarged up to the point where it allows ecological functionality. For M. paraguayanus, we found impermeable barriers to dispersal (urbanization and/or water bodies) in 10 buffers zones, eight of which included urban areas. Therefore, the buffer zones would have to be larger than proposed here, in order to guarantee sufficient habitat connectivity for the species to maintain minimum viable populations. We found a relationship between buffer zone size and forest cover, besides differences in this cover forest along protected areas, but the relationship is complex, indicating that other factors must be taken into account when determining buffer size.

For example, an important issue is matrix quality, which determines the possibility of biological flow (Crooks \& Sanjayan 2006). Although in Brazil buffer zones are generally in private properties (Vitalli et al. 2009), it is important that public policies incentive land uses which increase matrix permeability, as in the implementation of agroforestry systems (McNeely \& Schroth 2006). This can facilitate the dispersal of organisms establishing a flexible network among protected areas, and their surrounding habitat forests, and also enabling the maintenance of viable populations of the landscape of species. Indeed, higher variance in the estimated buffer size shows that these effects must be more important for smallest protected. Thus, it is necessary to increase the buffer size or small and isolated protected areas to size up its total area to a threshold to allow population viability. If it is impossible, buffer zone (and their fragments) should be viewed as a strategy for improving landscape connectivity.

In conclusion, our aim here was to propose a new way to achieve buffer zones with information on minimum habitat necessary to maintain viable population. The method proposed here provides a simple analysis that can be used to establish the limits of buffer zones.

\section{Acknowledgements}

Mariana Vale, Mirian Plaza Pinto and Valeska B. Oliveira for comments and suggestions in the earlier version, and José Alexandre F. Diniz-Filho provided help with spatial analyses. FAPERJ, CNPq and Conservation International-Brazil for financial support. Capes and Faperj for a scholarship to Renato Crouzeilles, and CNPq for Productivity fellowship to Carlos E. V. Grelle and ESRI that provided a free version of ArcGis 9.3.1.

\section{References}

Albernaz ALKM \& Souza MA, 2007. Planejamento sistemático para a conservação na Amazônia brasileira - uma avaliação preliminar das areas prioritárias de Macapá-99. Megadiversidade, 3:87-101.

Brito D \& Grelle CEV, 2004. Effectiveness of a reserve network for the conservation of the endemic marsupial Micoureus travassosi in Atlantic Forest remnants in Southeastern Brazil. Biodiversity and Conservation, 13:2519-2536.

Brito D \& Grelle CEV, 2006. Estimating minimum area of suitable habitat and viable population size for the Northern Muriqui (Brachyteles hypoxanthus). Biodiversity and Conservation, 15:4197-4210.

Cáceres NC, Ghizoni-Jr IR \& Graipel ME, 2002. Diet of two marsupials, Lutreolina crassicaudata and Micoureus demerarae, in a coastal Atlantic Forest island of Brazil. Mammalia, 66:331-340.

Caro T et al., 2004. Preliminary assessment of the flagship species concept at a small scale. Animal Conservation, 7:63-70.

Crooks KR \& Sanjayan M, 2006. Connectivity conservation. Cambridge: Cambridge University Press.

Cunha AA \& Grelle CEV, 2008. Landscape species for conservation planning: are muriquis good candidates for the Brazilian Atlantic Forest? Natureza \& Conservação, 6:17-24.

Cunha, AA, Grelle CEV \& Boubli JP. 2009. Distribution, population size and conservation of endemic muriquis (Brachyteles spp.) of the Brazilian Atlantic forest. Oryx, 43:254-257.

ESRI, 2008. ArcView 9.3. California, U.S.A.: Redlands.

Ficetola GF \& Denoël M, 2009. Ecological thresholds: on the correct assessment of abrupt and gradual changes. Ecography, 32:1075-1084.

Fidalgo ECC et al., 2009. Distribuição dos remanescentes vegetais no Estado do Rio de Janeiro. In: Bergallo HC et al. Estratégias e ações para a conservação da biodiversidade no Estado do Rio de Janeiro. Rio de Janeiro, Instituto Biomas. p. 91-99.

Forero-Medina G \& Vieira MV, 2009. Perception of a fragmented landscape by Neotropical marsupials: effects of body mass and environmental variables. Journal of Tropical Ecology, 25:53-63.

Fundação SOS Mata Atlântica \& Instituto Nacional de Pesquisas Espaciais - INPE, 2010. Atlas dos remanescentes florestais da Mata Atlântica no período de 2008-2010. São Paulo.

Gonçalves CN et al., 2009. Buffer zone: creation or delimitation? Natureza \& Conservação, 7:38-43.

Grelle, CEV, 2003. Forest structure and vertical stratification of small mammal populations in a secondary forest, South-eastern Brazil. Studies on Neotropical Fauna \& Environment, 38:81-85.

Grelle, CEV, Lorini, ML \& Pinto, MP. 2010. Reserve selection based on vegetation in the Brazilian Atlantic forest. Natureza \& Conservação, 8:46-53. 
Harper EB et al., 2008. Demographic Consequences of Terrestrial Habitat Loss for Pool-Breeding Amphibians: Predicting Extinction Risks Associated with Inadequate Size of Buffer Zones. Conservation Biology, 22:1205-1215

Hunter-J ML, Bean MJ \& Lindenmayer DB, 2009. Thresholds and the Mismatch between Environmental Laws and Ecosystems. Conservation Biology, 23:1053-1055.

Jenkins CN, Alves MAS \& Pimm SL, 2010. Avian conservation priorities in a top-ranked biodiversity hotspot. Biological Conservation, 143:992-998.

Legendre, P. \& Legendre, L. 1998. Numerical Ecology. $2^{\text {nd }} e d$. Amsterdan: Elsevier.

McNeely J \& Schroth G, 2006. Agroforestry and biodiversity conservation - traditional practices, present dynamics, and lessons for the future. Biodiversity and Conservation, 15:549-554.

Passamani M \& Ribeiro D, 2009. Small mammals in a fragment and adjacent matrix in southeastern Brazil. Brazilian Journal of Biology, 69:305-309.

Pires AS et al., 2002. Frequency of movements of small mammals among Atlantic Coastal Forest fragments in Brazil. Biological Conservation, 108:229-237.
Rangel TF, Diniz-Filho JAF \& Bini LM, 2010. SAM: A comprehensive application for spatial analysis in macroecology. Ecography, 33:46-50.

Rossi, RV, Bianconi, GV \& Pedro, WA. 2006. Ordem Didelphimorphia. In: Reis N, Peracchi AL \& Pedro WA. Mamíferos do Brasil. Londrina: Ed. Universidade Estadual de Londrina. p. 27-66

Sanderson EW et al., 2002. A conceptual model for conservation planning based on landscape species requirements. Landscape and Urban Planning, 58:41-46.

Umetsu F, Metzger JP \& Pardini R, 2008. The importance of estimating matrix quality for modeling species distribution in complex tropical landscape: a test with Atlantic forest small mammals. Ecography, 31:359-370.

Vitalli PL, Zakia MJB \& Durigan G, 2009. Considerações sobre a legislação correlata à zona tampão de Unidades de Conservação no Brasil. Ambiente \& Sociedade, 12:67-82.

Received: September 2010

First Decision: September 2010 Accepted: October 2010 